\title{
TRUNK AND LEG GROWTH IN CHILDREN WITH PARAPLEGIA CAUSED BY SPINAL CORD INJURY
}

\author{
By .G. Duval-Beaupere, M.D., ${ }^{1}$ J. Lougovoy, M.D., ${ }^{2}$ L. Trocellier, \\ M.D. ${ }^{2}$ and Ph. LACERT, M.D. ${ }^{3}$ \\ ${ }^{1}$ Maître de Recherche Inserm, Unité 215 , Attaché de Neuro-Orthopédie, Hôpital \\ $R$. Poincaré, Garches. ${ }^{2}$ Médecins de Centre de Rééducation Motrice pour tous-Petits, \\ Centre Elisabeth de la Panouse-Debré, 37 rue fulien Périn, 92160 Antony. \\ ${ }^{3}$ Professeur, Médecin des Hôpitaux, Hôpital R. Poincaré, 92380 Garches, France
}

Summary. After a survey of the bibliography on the subject of clinical and experimental data on retarded growth in children affected by lesions of the peripheral nervous system, the authors present a semi-longitudinal analysis of the anthropometric values obtained by spinal cord section in the case of young paraplegics. By this means, they demonstrate an average growth defect of the order of two standard deviations which only affects the body distal to the neurological lesion in cervical or dorsal injuries. The lower the level of the cord lesion and the earlier the paralysis the greater the growth defects.

Key words: Paraplegic children; Defect of trunk and leg growth.

\section{Introduction}

THE EFFECT of trunk and limb growth by the nervous system had been clinically demonstrated by the unequal leg lengths resulting from asymmetrical damage caused by acute anterior poliomyelitis (AAP). However the mechanism of this action is not yet quite clear.

Various clinical investigations (Bara, I948; Blount, I956; Fanconi et al., I959; Ratliff, I959; Ring, I957a and b, I958; Salaire, I963; Taillard, I959) have stressed the frequency of these inequalities, as well as the fact that their development is delayed until after an irregular phase of excessive growth. This initial phase, which Frost (1979) calls 'the regional acceleratory phenomenon', is not peculiar to nervous damage but is common to all major injuries and suggests reactional acceleration of local metabolism. The subsequent evolution of these limb length discrepancies, which affect the femur and tibia but mostly the latter, varies considerably, and at maturity they may measure anything from $I \cdot 5-9 \mathrm{~cm}$. Their final length is not statistically correlated with the age of the patient when the injury occurs (Gullickson et al., I950; Ratliff, I959; Stinchfield et al., 1949), and although it does correlate with the relative degree of paralysis, the correlation is so variable that no forecast is possible (Gill \& Abott, I942; Green, I949; Ring, I957; Stinchfield et al., I949).

Most studies have been unable to show any relationship between the size of the discrepancy and paralysis of a particular muscle. Only Florensa (I965) stressed the very frequent association of the shortest femur with the most paralysed quadriceps, and the even more frequent one between the shortest tibia and the most paralysed gastrocnemius. Both this author and Trott (I968) emphasised the relationship between unequal length and neurovegetative disturbances such as cyanosis and cold. In this connection, 
clinical experience shows that all methods of selectively heating the most severely paralysed limb can be effective.

Research on nerve growth relationship has explored three different possibilities regarding the above data: that there is direct effect on the growth cartilage, or that it acts through mechanical disturbances which follow paralysis, or by vascular changes.

Various animal experiments have demonstrated that neural section above only affects growth moderately or not at all (Selye \& Bajusk, I958; Showing \& Celers, I965; Troupp, I96I). These studies show that bone morphology abnormalities are generated by mechanical disorders, but conclude that such abnormalities are in no way responsible for deficient growth in the length of long bones (Trueta, I960, I96I).

Frost (I979) contests the validity of this last conclusion on the grounds of possible interference of regional growth phenomena. On the basis of clinical findings, he puts forward a chondral modelling theory which postulates that chondral growth responds triphasically to mechanical loads. According to Frost, the growth deficiency in paralysis constitutes such a response. He admits that such a reaction involves changes in metabolism, including possible variations in the blood supply.

Other experiments have verified the vital part played in the growth of bone length by insufficient vascularisation (Showing \& Celers, I965; Troupp, I96I; Trueta, I958, I960, I96I; Van der Hoeft et al., I963; Wo \& Mittner, I937), and hypoxia (Person, I968), and this is why the resulting inequalities were attributed to the vascular effects of neurological damage. The mechanism of such consequences has not yet been investigated. The hypothesis that neurovegetative disturbances are caused by injury to the tractus intermedio-lateralis of the spinal cord was opposed by Trott (I958, I 968 ) because of the delayed occurrence of vasomotor disorders in poliomyelitis subjects and the fact that they preserve vasoconstrictor reflexes in response to cold and indirect vasodilation. The same author therefore suggested that these vasomotor disorders should be considered to be an expression of a reflex of adaptation to lower consumption by paralysed muscles. The influence of the sympathetic nervous system on vascularisation of bone marrow has been confirmed (Herzig \& Root, I969). Its effect on blood flow could not be demonstrated by the residue function technique (McEilfresh \& Kelly, I974), but this negative result could be due to the depression of the central system by the necessity to anaesthetise necessary laboratory animals (Herzig \& Root, I969). Florenza (I965) and Lecoeur (I98I) stressed that muscles with a wide periosteal insertion provide bone with numerous nutritive vessels, and expressed the view that because of this, paralysis of these muscles may deprive the bones of an appreciable vascular supply. De Valderama \& Trueta (I965) showed that muscle contraction acts like a vascular bone pump. In the light of these different investigations, insufficient vascularisation in paralysed patients does therefore appear to be multifactorial.

In an earlier clinical study of pubertal development of certain poliomyelitis patients, we suggested a new transversal approach to the anthropometric consequences of paralytic injury (Duval-Beaupere \& Soulignac, I975). Until then, these consequences had only been examined from the viewpoint of unequal lower limb length. We studied the segmental growth of these limbs, in which growth disturbances had hitherto been 
neglected or ignored, disregarding the shortest one and measuring the longest. The result was that the longest limb in fact displayed a mean growth defect of two standard deviations. The same study also showed that when the trunk is subject to identical conditions of paralysis, it does not exhibit growth defects.

Apart from hemiplegia, paralytic injuries other than AAP are often symmetrical in children and do not give rise to lower limbs of unequal length. This is no doubt why the consequent repercussions of such injuries on lower limb growth have never been studied. Nevertheless, examination of their clinical neurological effects may perhaps provide additional information on the relationship between growth and the nervous system.

Subjects with paraplegia from spinal cord damage seemed to us to form a relatively homogeneous group on account of their precise level of cord injury, the syndrome and the sublesional automatic activity. We therefore felt that the study of such a group might throw new light on the nervous system-growth relationship, and this is why the present investigation was undertaken.

\section{Population and Working Method}

The study which follows is semilongitudinal and is based on the retrospective analysis of the documents relating to the medical observation of I I 4 children ( 70 boys and 44 girls) suffering from traumatic paraplegia. After hospitalisation, these patients were regularly followed up throughout their growth period by the neurological rehabilitation centres at Antony (Dr Lougovoy) and Garches (Profs Grossiord and Held), in the Paris area.

Most of the children were French, but they also included two girls and five boys from North Africa, one girl and two boys from Portugal, and two negro boys.

As Table I shows, the aetiology of the paraplegia was traumatic or neoplastic in 70 per cent of cases. Table II gives the histograms of these subjects' upper myelomeres. They were regressive in six boys and four girls, and neurologically incomplete but static in 20 boys and I 6 girls.

The following anthropometric values were ascertained: height $(\mathrm{H})$,

TABLE I

Aetiology of the paraplegia

\begin{tabular}{|c|c|c|}
\hline Aetiology & Male & Female \\
\hline $\begin{array}{l}\text { Traumatic } \\
\text { Arthrodesis of the fracture } \\
\text { Neoplastic } \\
\text { Radiotherapy } \\
\text { Vascular } \\
\text { Others } \\
\text { Abscess, myelitis, Pott's disease, } \\
\text { arachnoiditis, parasitosis, } \\
\text { congenital cord defect, (toxic causes) } \\
\text { Not determined }\end{array}$ & $\begin{array}{l}29 \\
\text { I } 8 \\
\text { I I } \\
\text { I } 2\end{array}$ & $\begin{array}{l}\text { I } 8 \\
\text { I } 4 \text { (2) } \\
{ }_{(\text {I I })} \\
6 \\
6\end{array}$ \\
\hline
\end{tabular}


TABLE II

Myelomeric level of paralysis

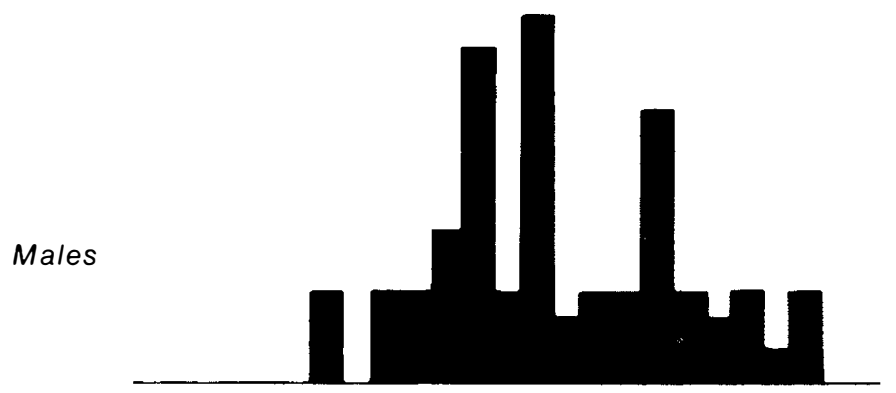

C1 $123456678^{\prime} T^{\prime} 1234456789101112 L 12345$

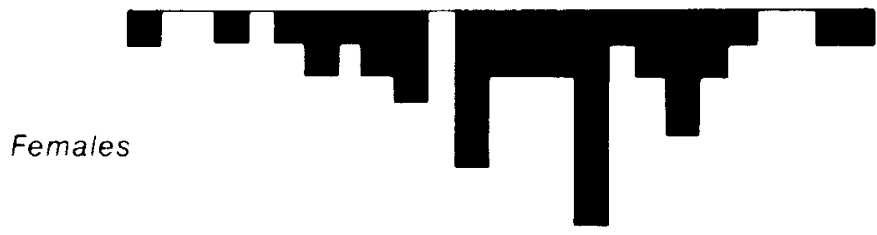

measured in the recumbent position as the distance from the vertex to the sole of the foot flexed at a right angle, and crown-rump or upper segment length (US), also measured in the recumbent position with the thighs flexed at a right angle. Subischial length, i.e. the lower segment (LS) was obtained by subtraction.

All values measured during growth were plotted on graphs, thus enabling the corresponding growth curves to be obtained by smoothing. Measurements were taken at each birthday, making it possible to calculate the corresponding means for each age and compare them by Student Fischer Test with the equivalent theoretical values. ${ }^{\star}$

The paraplegic level of the upper myelomeres from $\mathrm{C}_{1}$ to $\mathrm{L}_{5}$ were quantified by grading from one to 25. Another grading scale quantified the semester of the onset of paraplegia. This period, which started from the birthday, was expressed as the corresponding age, and the following semester, as one and half times the corresponding age. These grading scales permitted statistical study of the correlations of the level of paralysis with the period which had elapsed since its onset.

\section{Results}

\section{Changes in growth}

Tables III and IV show the means obtained for each age, segment and sex, and the results of the statistical test.

* The values taken as theoretical are those given by Sempé and Roy for the French sample of the International Longitudinal Growth Survey, co-ordinated by the CIE (Prof. F. Faulkner). 
TABLE III

Mean $\mathrm{H}$, US and LS values for girls

\begin{tabular}{|c|c|c|c|c|c|c|c|c|c|c|c|c|c|c|c|c|c|c|c|c|c|c|}
\hline \multirow[t]{3}{*}{ Age } & \multicolumn{4}{|c|}{ Paraplegia } & \multicolumn{6}{|c|}{$\mathrm{H}$} & \multicolumn{6}{|c|}{ US } & \multicolumn{6}{|c|}{ LS } \\
\hline & \multicolumn{2}{|c|}{$\begin{array}{l}\text { Mean age } \\
\text { at onset }\end{array}$} & \multicolumn{2}{|c|}{$\begin{array}{c}\text { Mean } \\
\text { level }\end{array}$} & \multicolumn{3}{|c|}{ Paraplegics } & \multirow[t]{2}{*}{$\begin{array}{l}\text { Signifi- } \\
\text { cance }\end{array}$} & \multicolumn{2}{|c|}{ Theoretical } & \multicolumn{3}{|c|}{ Paraplegics } & \multirow[t]{2}{*}{$\begin{array}{l}\text { Signifi- } \\
\text { cance }\end{array}$} & \multicolumn{2}{|c|}{ Theoretical } & \multicolumn{3}{|c|}{ Paraplegics } & \multirow[t]{2}{*}{$\begin{array}{l}\text { Signifi- } \\
\text { cance }\end{array}$} & \multicolumn{2}{|c|}{ Theoretical } \\
\hline & $\mathrm{m}$ & SD & $\mathrm{m}$ & SD & $n$ & $\mathrm{~m}$ & SD & & $\mathrm{m}$ & SD & $n$ & $\mathrm{~m}$ & SD & & $\mathrm{m}$ & SD & $n$ & $\mathrm{~m}$ & SD & & $\mathrm{m}$ & SD \\
\hline$I$ an & 0.14 & 0.2 & D8 & $4 \cdot 8$ & II & $71 \cdot 8$ & 2.9 & NS & $72 \cdot 6$ & 2.5 & 9 & $46 \cdot 2$ & 1.9 & NS & $45 \cdot 8$ & I. 6 & 9 & 25.7 & $I \cdot 3$ & $S^{\star}$ & 26.8 & I. 6 \\
\hline 2 & 0.36 & 0.5 & D8 & $5 \cdot 1$ & 14 & $80 \cdot 7$ & $4 \cdot 6$ & $S^{\star \star}$ & $84 \cdot 3$ & $3 \cdot 1$ & I I & $50 \cdot 7$ & $3 \cdot 1$ & NS & $51 \cdot 0$ & $\mathrm{I} \cdot 8$ & II & 30.0 & $2 \cdot 3$ & $S^{\star \star \star}$ & $33 \cdot 3$ & $\mathrm{I} \cdot 8$ \\
\hline 3 & 0.63 & 0.8 & D8 & 50 & 16 & $86 \cdot 5$ & 4.5 & $S^{\star \star \star}$ & 92.7 & $3 \cdot 3$ & 15 & 54.0 & 3.0 & NS & 549 & $I \cdot 9$ & 15 & 35.8 & $2 \cdot 6$ & $S^{\star \star}$ & 37.8 & $2 \cdot 0$ \\
\hline 4 & 0.79 & 0.8 & $\mathrm{D}_{7}$ & $5 \cdot 2$ & 17 & 96.8 & 5.6 & $S^{\star}$ & $99 \cdot 8$ & $3 \cdot 6$ & 16 & $57 \cdot 2$ & 3.8 & NS & $57 \cdot 9$ & $2 \cdot I$ & 16 & $40 \cdot I$ & $2 \cdot 6$ & $S^{\star}$ & $4 \mathrm{I} \cdot 9$ & $2 \cdot 2$ \\
\hline 5 & I. 18 & I. 4 & $\mathrm{D}_{6} \mathrm{D}_{7}$ & 5.5 & 17 & 103.7 & 6.4 & NS & $106 \cdot 3$ & $4 \cdot 0$ & 13 & $59 \cdot 8$ & 4.5 & NS & $60 \cdot 2$ & $2 \cdot 3$ & 13 & $44 \cdot 3$ & $3 \cdot 8$ & NS & $46 \cdot 2$ & $2 \cdot 3$ \\
\hline 6 & 1.85 & $\mathrm{I} \cdot 8$ & D6 & 5.9 & 13 & $109 \cdot 7$ & $7 \cdot 3$ & NS & 112.2 & 4.2 & 9 & $63 \cdot 3$ & 50 & NS & $62 \cdot 6$ & 2.5 & 9 & $47 \cdot 4$ & $4 \cdot 3$ & NS & $49 \cdot 6$ & $2 \cdot 4$ \\
\hline 7 & $2 \cdot 27$ & $2 \cdot I$ & $\mathrm{D}_{7}$ & 49 & II & 114.7 & 9.0 & NS & II 8.2 & $4 \cdot 6$ & 8 & 65.7 & 5.5 & NS & $64 \cdot 9$ & 2.5 & 8 & 50.8 & $5 \cdot 6$ & NS & $53 \cdot 3$ & $2 \cdot 7$ \\
\hline 8 & 3.21 & 3.0 & D5 & 5.2 & 12 & 118.2 & $9 \cdot 2$ & NS & 123.9 & $4 \cdot 8$ & 9 & $67 \cdot 8$ & 5.7 & NS & $67 \cdot 2$ & $2 \cdot 4$ & 9 & $51 \cdot 6$ & 5.9 & $S^{\star}$ & $56 \cdot 7$ & $2 \cdot 9$ \\
\hline 9 & $4 \cdot 20$ & $3 \cdot 3$ & D6 & 3.9 & 9 & 123.9 & $4 \cdot 3$ & $S^{\star}$ & 129.4 & 5.0 & 8 & $71 \cdot 2$ & $3 \cdot 3$ & NS & $69 \cdot 2$ & 2.5 & 8 & 55.9 & $5 \cdot 6$ & NS & $60 \cdot 2$ & 3.0 \\
\hline 10 & 4.45 & 3.5 & Ds & 5.4 & IO & 128.5 & $4 \cdot 8$ & $S^{\star \star}$ & 134.7 & 5.3 & 8 & $72 \cdot 7$ & 3.1 & NS & $7 I \cdot 3$ & $2 \cdot 6$ & 9 & 55.6 & $4 \cdot 7$ & $S^{\star \star}$ & 63.4 & $3 \cdot 7$ \\
\hline I I & 4.45 & 3.5 & $\mathrm{D}_{4} \mathrm{D}_{5}$ & $6 \cdot 3$ & 10 & 132.8 & $6 \cdot 4$ & $S^{\star \star}$ & $140 \cdot 7$ & $5 \cdot 7$ & 8 & 74.0 & $3 \cdot 8$ & NS & $74 \cdot 0$ & $2 \cdot 9$ & 9 & 58.3 & $5 \cdot 1$ & $S^{\star \star}$ & $66 \cdot 7$ & $3 \cdot 3$ \\
\hline 12 & 5.71 & $4 \cdot 6$ & $\mathrm{D}_{5}$ & $6 \cdot 4$ & 9 & $138 \cdot 1$ & 8.6 & $S^{\star \star}$ & 147.7 & $6 \cdot 4$ & 8 & 77.9 & 5.0 & NS & 77.5 & $3 \cdot 3$ & 9 & $62 \cdot 7$ & $7 \cdot 5$ & $S^{\star}$ & $70 \cdot 2$ & $3 \cdot 6$ \\
\hline 13 & 6.00 & $5 \cdot 3$ & $\mathrm{D}_{5}$ & 5.4 & 12 & 146.4 & $8 \cdot 3$ & $S^{\star \star}$ & 154.3 & $6 \cdot 1$ & 8 & $8 \mathrm{I} \cdot 2$ & 5.0 & NS & $8 \mathrm{I} \cdot \mathrm{I}$ & 3.5 & 9 & $66 \cdot 8$ & 5.7 & $S^{\star \star}$ & $73 \cdot 2$ & 3.5 \\
\hline 14 & $7 \cdot 46$ & $5 \cdot 1$ & D7 & $4 \cdot 2$ & 14 & $151 \cdot 9$ & $6 \cdot 7$ & $S^{\star \star}$ & 158.7 & $5 \cdot 7$ & 10 & $84 \cdot 8$ & $4 \cdot 6$ & NS & $84 \cdot 2$ & $3 \cdot 3$ & II & $67 \cdot 2$ & $4 \cdot 6$ & $S^{\star \star \star}$ & 74.5 & 3.4 \\
\hline 15 & $6.6 \mathrm{I}$ & 4.7 & $\mathrm{D}_{4} \mathrm{D}_{5}$ & $4 \cdot 3$ & 9 & 151.4 & $4 \cdot 8$ & $S^{\star \star \star}$ & $\mathrm{I} 6 \mathrm{I} \cdot \mathrm{I}$ & $5 \cdot 7$ & 5 & $84 \cdot 2$ & 4.5 & NS & $86 \cdot I$ & $3 \cdot 2$ & 5 & $67 \cdot I$ & 7.9 & NS & 75.0 & $3 \cdot 4$ \\
\hline 16 & 4.60 & $4 \cdot 2$ & D8 & $2 \cdot 2$ & 5 & 150.0 & 40 & $S^{\star \star}$ & 162.4 & $5 \cdot 6$ & 3 & 83.2 & $4 \cdot 8$ & NS & $87 \cdot 3$ & 3.0 & 3 & $66 \cdot 2$ & I. 3 & $S^{\star \star \star}$ & $75 \cdot \mathrm{I}$ & 3.4 \\
\hline 17 & $4 \cdot 38$ & 4.8 & D9 & I. 4 & 4 & 1517 & $2 \cdot 2$ & $S^{\star \star \star}$ & 162.9 & $5 \cdot 6$ & 2 & $86 \cdot 2$ & I. 8 & NS & $87 \cdot 8$ & 3.0 & 2 & $66 \cdot 2$ & $\mathrm{I} \cdot 8$ & $S^{\star \star \star \star}$ & $75 \cdot \mathrm{I}$ & $3 \cdot 4$ \\
\hline
\end{tabular}


TABLE IV

Mean H, US and LS values for boys

\begin{tabular}{|c|c|c|c|c|c|c|c|c|c|c|c|c|c|c|c|c|c|c|c|c|c|c|}
\hline \multirow[t]{3}{*}{ Age } & \multicolumn{4}{|c|}{ Paraplegia } & \multicolumn{6}{|c|}{$\mathrm{H}$} & \multicolumn{6}{|c|}{ US } & \multicolumn{6}{|c|}{ LS } \\
\hline & \multicolumn{2}{|c|}{$\begin{array}{l}\text { Mean age } \\
\text { at onset }\end{array}$} & \multicolumn{2}{|c|}{$\begin{array}{c}\text { Mean } \\
\text { level }\end{array}$} & \multicolumn{3}{|c|}{ Paraplegics } & \multirow[t]{2}{*}{$\begin{array}{l}\text { Signifi- } \\
\text { cance }\end{array}$} & \multicolumn{2}{|c|}{ Theoretical } & \multicolumn{3}{|c|}{ Paraplegics } & \multirow[t]{2}{*}{$\begin{array}{l}\text { Signifi- } \\
\text { cance }\end{array}$} & \multicolumn{2}{|c|}{ Theoretical } & \multicolumn{3}{|c|}{ Paraplegics } & \multirow[t]{2}{*}{$\begin{array}{l}\text { Signifi- } \\
\text { cance }\end{array}$} & \multicolumn{2}{|c|}{ Theoretical } \\
\hline & $\mathrm{m}$ & SD & $\mathrm{m}$ & SD & $n$ & $\mathrm{~m}$ & SD & & $\mathrm{m}$ & SD & $n$ & $\mathrm{~m}$ & SD & & $\mathrm{m}$ & SD & $n$ & $\mathrm{~m}$ & $\mathrm{SD}$ & & $\mathrm{m}$ & SD \\
\hline$I$ an & 0.14 & 0.3 & D9 & 48 & I I & 73.4 & $3 \cdot I$ & NS & $74 \cdot 3$ & $2 \cdot 4$ & 10 & $46 \cdot I$ & $2 \cdot 3$ & NS & $46 \cdot 9$ & $\mathrm{I} \cdot 8$ & IO & $26 \cdot 8$ & I. 6 & NS & 27.4 & I. 5 \\
\hline 2 & 0.38 & 0.5 & D8 & 37 & 17 & $84 \cdot 5$ & 4.5 & NS & 85.6 & 3.0 & 15 & 518 & $2 \cdot 8$ & NS & $52 \cdot I$ & I. 9 & 15 & $32 \cdot 3$ & $2 \cdot 3$ & NS & 33.5 & I. 8 \\
\hline 3 & 0.64 & 0.7 & $\mathrm{D}_{7}$ & 3.7 & 22 & $91 \cdot 8$ & 44 & $S^{\star}$ & 94.2 & 3.5 & 20 & 54.9 & $2 \cdot 6$ & NS & $56 \cdot 0$ & $2 \cdot 0$ & 20 & $36 \cdot 7$ & $2 \cdot 3$ & $S^{\star \star}$ & $38 \cdot 2$ & 2.0 \\
\hline 4 & 1.02 & I. 2 & $\mathrm{D}_{7}$ & $4 \cdot I$ & 22 & 98.6 & 50 & $S^{\star}$ & $101 \cdot 3$ & 3.9 & 17 & 57.8 & 2.5 & NS & 58.9 & $2 \cdot 2$ & 17 & $40 \cdot 2$ & $2 \cdot 7$ & $S^{\star \star}$ & $42 \cdot 4$ & $2 \cdot 2$ \\
\hline 5 & I. 48 & I. 6 & $\mathrm{D}_{7}$ & $4 \cdot \mathrm{I}$ & 23 & 104.4 & 49 & $S^{\star \star}$ & 107.7 & $4 \cdot 2$ & 20 & $6 \mathrm{I} \cdot \mathrm{I}$ & 2.9 & NS & $6 \mathrm{I} \cdot 2$ & $2 \cdot 3$ & 20 & $43 \cdot 6$ & 3.5 & $S^{\star \star}$ & $46 \cdot 5$ & 2.4 \\
\hline 6 & I. 60 & I $\cdot 8$ & D7 & 39 & 20 & III 6 & $5 \cdot 5$ & NS & 113.8 & 47 & 15 & $64 \cdot 2$ & $3 \cdot 2$ & NS & $63 \cdot 6$ & 2.5 & I 6 & $46 \cdot 8$ & 46 & $S^{\star \star}$ & $50 \cdot 2$ & 2.5 \\
\hline 7 & $2 \cdot 10$ & I. 9 & D6 & 40 & 20 & 117.9 & 5.5 & NS & 119.7 & 4.9 & I 6 & 67.0 & 3.4 & $S^{\star}$ & $65 \cdot 8$ & $2 \cdot 6$ & 17 & $50 \cdot 3$ & $4 \cdot 8$ & $S^{\star \star}$ & 53.9 & 2.7 \\
\hline 8 & 3.23 & $2 \cdot 4$ & $\mathrm{D}_{5}$ & 36 & 20 & 124.2 & $5 \cdot 2$ & NS & 125.1 & $5 \cdot 1$ & 18 & $69 \cdot 2$ & $2 \cdot I$ & $S^{\star}$ & $68 \cdot 0$ & $2 \cdot 8$ & 18 & $54 \cdot 6$ & $4 \cdot 2$ & $S^{\star}$ & 57.3 & 29 \\
\hline 9 & 3.70 & 2.5 & D6 & $4 \cdot I$ & 20 & 129.3 & 5.7 & NS & 130.6 & $5 \cdot 3$ & 17 & $70 \cdot 2$ & 3.3 & NS & $70 \cdot \mathrm{I}$ & $2 \cdot 8$ & 17 & 58.9 & 47 & NS & 60.5 & 3.0 \\
\hline IO & 3.80 & 2.5 & D6 & $4 \cdot \mathrm{I}$ & 19 & 133.9 & 6.5 & NS & 135.6 & 5.3 & 17 & $72 \cdot 7$ & $4 \cdot I$ & NS & $71 \cdot 9$ & $2 \cdot 8$ & 17 & $62 \cdot 5$ & 5.9 & NS & 63.7 & 3.2 \\
\hline I I & 4.80 & $3 \cdot 2$ & D6 & 37 & 21 & 138.7 & $6 \cdot 8$ & NS & 140.5 & 5.7 & 16 & 74.9 & $4 \cdot I$ & NS & 73.8 & 2.9 & 16 & $63 \cdot 8$ & $6 \cdot 0$ & NS & $66 \cdot 7$ & 3.4 \\
\hline I 2 & $5 \cdot 10$ & $3 \cdot 8$ & $\mathrm{D}_{7}$ & $4 \cdot \mathrm{I}$ & 25 & 143.6 & $7 \cdot 1$ & NS & 145.8 & $6 \cdot I$ & 20 & $77 \cdot 2$ & 3.7 & NS & $76 \cdot \mathrm{I}$ & $3 \cdot 2$ & 20 & $66 \cdot 3$ & $6 \cdot I$ & $S^{\star}$ & $69 \cdot 7$ & 37 \\
\hline 13 & $6 \cdot 10$ & $4 \cdot 2$ & $\mathrm{D}_{7}$ & 39 & 23 & I 47.4 & $7 \cdot 4$ & $S^{\star \star}$ & 152.5 & $7 \cdot 3$ & 19 & $79 \cdot 9$ & 3.6 & NS & $79 \cdot \mathrm{I}$ & 3.8 & 19 & $67 \cdot 2$ & $6 \cdot 3$ & $S^{\star \star \star}$ & 73.4 & $4 \cdot \mathrm{I}$ \\
\hline 14 & 6.40 & 4.5 & $\mathrm{D}_{7}$ & 43 & 22 & 153.3 & $6 \cdot 8$ & $S^{\star \star \star}$ & 159.9 & $8 \cdot I$ & I8 & 82.9 & $2 \cdot 4$ & NS & $83 \cdot 2$ & 49 & 18 & 70.3 & 6.4 & $S^{\star \star \star}$ & $76 \cdot 7$ & 4.0 \\
\hline 15 & 7.50 & 5.4 & $\mathrm{D}_{7}$ & 40 & 23 & $159^{\circ} 2$ & 6.9 & $S^{\star \star \star}$ & 166.7 & 7.0 & 17 & $86 \cdot 6$ & 3.0 & NS & 87.3 & 46 & 17 & $72 \cdot 6$ & $6 \cdot 0$ & $S^{\star \star \star}$ & $79 \cdot 4$ & 39 \\
\hline 16 & $9 \cdot 00$ & 5.3 & $\mathrm{D}_{7}$ & 30 & 14 & 163.3 & 6.4 & $S^{\star \star \star}$ & $171^{\prime} 1$ & $6 \cdot 0$ & 8 & $87 \cdot 7$ & $3 \cdot 7$ & NS & $90 \cdot 4$ & 40 & 8 & 75.9 & 6.4 & NS & $80 \cdot 7$ & 3.6 \\
\hline 17 & $7 \cdot 40$ & 6.4 & $\mathrm{D}_{7}$ & 34 & IO & 165.7 & $6 \cdot 5$ & $S^{\star \star}$ & 173.5 & 6.0 & 6 & 90.9 & 5.7 & NS & $92 \cdot 3$ & 3.5 & 6 & $74 \cdot 2$ & $7 \cdot 8$ & NS & $8 \mathrm{I} \cdot 2$ & 3.6 \\
\hline 18 & 7.70 & $6 \cdot 4$ & $\mathrm{D}_{5}$ & 48 & 8 & 166.6 & 6.9 & $S^{\star}$ & 174.5 & $6 \cdot 0$ & 4 & $9 \mathrm{I} \cdot 7$ & $4 \cdot 2$ & NS & $93 \cdot 2$ & 3.5 & 4 & $70 \cdot 0$ & $7 \cdot 8$ & $S^{\star}$ & $8 \mathrm{I} \cdot 3$ & 3.6 \\
\hline
\end{tabular}


Defective vertex-to-sole growth $(\mathrm{H})$ was of the order of one standard deviation, due to defective growth of the lower segment (LS) of the order of two standard deviations, but growth of the upper segment (US) revealed no evident change. These modifications were constant for all ages and both sexes, and were nearly always significant. The US was sometimes found to be slightly longer, but the difference was only significant for two values.

\section{Factors affecting deficient growth}

Level of injury. This was estimated by calculating the correlation/coefficients for the parameters US and LS, using the I-25 grading scale to obtain the upper myelomeric level of paralysis for the 5, 7, 8, I 3, I 4 and I 5-year agegroups in boys and the 4, I I and I 4 age-groups in girls.

Only one correlation coefficient was found to be significant: in 7-yearold boys, the lower the level of injury the shorter the LS (SD $=0.570$, $n=\mathrm{I} 6$, Table VI).

Time elapsing since paralysis. The factors role was appreciated by calculating the correlation coefficient for the same age-groups.

In I 5-year-old boys, the earlier the paralysis, the shorter the LS (SD = $0.570, n=\mathrm{I} 6$ ).

The same applied to the girls of I 4 years $(\mathrm{SD}=0.680, n=\mathrm{I} \mathrm{I})$.

Flaccid or spastic nature of paraplegia. In the boys, mean LS values for flaccid and spastic cases were compared at 7, I 2 and I3 years. Mean flaccid LS were shorter than mean spastic LS, but the difference cannot be considered significant.

TABLE V

Miean LS values for flaccid or spastic paraplegic boys

\begin{tabular}{lrccc}
\hline & & Flaccid & Spastic & $t$ \\
\hline \multirow{3}{*}{ 7 years } & LS & 48 & 52.05 & $\mathrm{I} \cdot 80$ \\
& $n$ & 7 & $\mathrm{I} 0$ & \\
& $\tau$ & 5.54 & 3.77 & \\
I2 years & $\mathrm{LS}$ & 62 & 67.57 & $\mathrm{I} \cdot 84$ \\
& $n$ & 5 & $\mathrm{I} 4$ & \\
& $\tau$ & 5.35 & 5.93 & \\
I3 years & $\mathrm{LS}$ & 64.33 & 68.38 & $\mathrm{I} \cdot \mathrm{I} 3$ \\
& $n$ & 6 & $\mathrm{I} 3$ & \\
& $\tau$ & 5.87 & $6.4 \mathrm{I}$ &
\end{tabular}

Degree of paraplegia. The effects of this factor were studied in the age-groups with the largest number of incomplete paraplegia: they included boys of 3 years (eight cases), I 2 years (six cases) and I 3 years (seven cases) and girls of 4 years (five cases) and 12 years (four cases). Comparison of the mean $\mathrm{H}$ and LS values for each sex showed that the two groups were not different, and that their mean values were very close to the general means.

Effects of radiotherapy. The only age-group large enough to permit assessment of these effects was the 5-year-old girls (seven cases). Comparison of mean $\mathrm{H}$, US and LS values in this group and in the 
Segmental values for boys of 7 years as a function of myelomeric levels

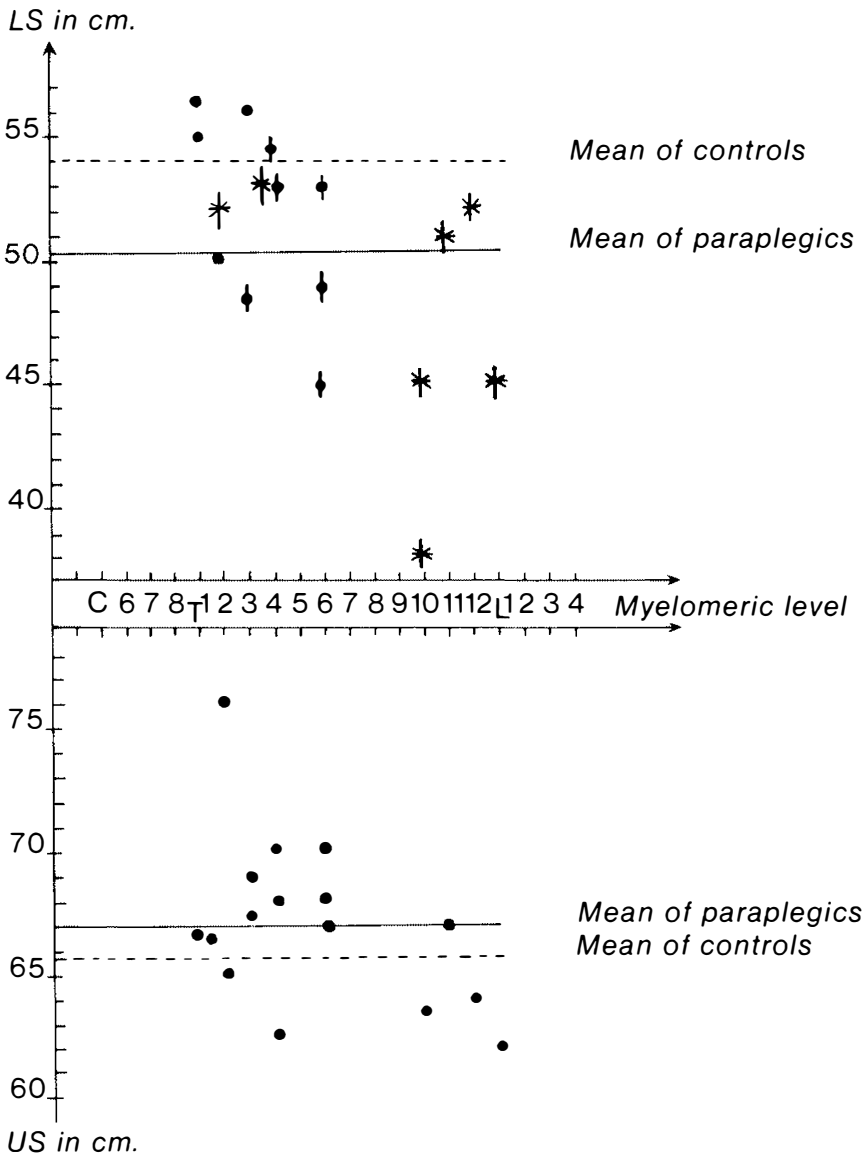

LS: $\bullet$ spastic, $\star$ flaccid, | injury dating back more than 5 years. US: $\bullet$ undifferentiated.

\section{TABLE VII}

Effect of Radiotherapy

Mean, H, US and LS values for 5-year-old girls

\begin{tabular}{lccc}
\hline & Irradiated & Non-irradiated & $t$ \\
\hline $\mathrm{H}$ & I03.29 & I04.05 & \\
$n$ & 7 & IO & 0.23 \\
$\tau$ & 6.46 & 6.67 & \\
$\mathrm{US}$ & 58.67 & 60.79 & \\
$n$ & 6 & 7 & 0.84 \\
$\tau$ & 4.46 & 4.64 & \\
$\mathrm{LS}$ & 44.92 & $43.7 \mathrm{I}$ & \\
$n$ & 6 & 7 & 0.55 \\
$\tau$ & 4.42 & 3.50 & \\
\hline
\end{tabular}


corresponding non-irradiated group showed that $\mathrm{H}$ and US were slightly shorter among the subjects irradiated, but the difference cannot be considered significant (Table VII).

Aetiology of paraplegia. Two aetiologies predominated, traumatic and neoplastic, and although it may have been interesting to compare their respective effects, we gave up the idea because of a third factor, the age at which paraplegia occurred. This mean age was very different for the two aetiologies and in itself might have affected the results, since in most of the neoplastic cases, paraplegia was evident at birth or during the first year of life.

\section{Conclusions}

The results of this study show that, like damage to the anterior horn cells, paraplegia in children caused by cord injury has repercussions on growth. These essentially concern the lower limbs, which at maturity display a growth deficiency of two standard deviations. This degree of deficiency is comparable to the one we showed for the longest limb in cases of asymmetrical poliomyelitic paraplegia. The comparison is also valid for trunk growth, since even in the presence of upper cervical or thoracic lesions, the upper segment exhibited normal growth. We even wonder if such growth was not, for a time, very slightly stimulated.

It is more difficult to draw conclusions about the factors liable to influence these changes in growth, since the population studied was distributed among several age-groups including at most 20 subjects per agegroup for each sex. There are probably many causes for the variations found in the anthropometric values. In addition to the primary genetic scatter of 6-I $2 \mathrm{~cm}$, depending on age, these causes no doubt include the extent of paralysis, its complete or incomplete character, whether flaccid or spastic, the period of time from the onset of paralysis and the duration of the regional accelatory phenomenon. Under these conditions, it seems difficult to hope to obtain significant coefficients of regression, apart from the existence of an extremely strong relationship between one of these causes and modifications in the growth of US and LS.

Nevertheless, taking due account of these considerations, it does seem possible to suggest a few possibilities concerning the factors which might affect the above growth defects. The latter certainly seem all the more serious as the lesion occurs early and its level is low. Although flaccidity appears to increase the growth deficiency, a larger group of subjects would be necessary to be certain that it plays an important part in this respect. Previous localised radiotherapy had no evident effects on statural growth. As regards the aetiology and the complete or incomplete nature of paralysis, it did not seem to us possible to assess the respective effects of these factors on deficient growth.

\section{Discussion}

It may seem curious that paralytic injury can have different effects on trunk and on limb growth, but even in the course of physiological growth, these two segments exhibit separate growth rates, probably because of the difference in the sensitivities to hormonal influences on the respective cartilages. Neurotomy does nothing to change cartilage sensitivity to 
ambient hormonal levels (Selye \& Bajusk, I958), and cannot therefore explain these discrepant growth phenomena. On the other hand, if insufficent vascularisation is accepted as a cause of defective growth, the spine would appear to be less endangered than the legs, since each vertebra has its own system of vascularisation, which is extremely rich, develops during growth (Mineiro, I965), and obviously depends less on muscular activity compared to long bone vascularisation. It therefore seems possible that following paralysis, vascularisation of the spine is less disturbed than it is of the long bones.

On the face of it, it is disconcerting to find that the most serious growth deficiencies can occur in subjects displaying what is in fact the least degree of paralysis. On further reflection, however, it becomes evident that the lower the myelomeric level of paraplegia, the greater the cumulative risks of defective vascularisation of the bones of the lower limbs, and the greater the weakening of the forces of compression created by muscle tonicity.

In this connection, for the myelomere levels above $T_{\text {I }}$, the medullary neurovegetative centres on which the lower limbs depend are located below the lesion and can therefore continue to function automatically, but as Jaeger Denavit et al. (I969) showed their response is diminished and they can only supply in part the needs of a spastic musculature which is often active below the lesion.

However, as soon as the myelomere level drops to between TI I and L2, these neurovegetative centres become part of the syndrome and are incapable of ensuring any regulation at all to cope with consumption by the sublesional spastic musculature.

When the level is lower still, there is, in addition to this inability, the risk of peripheral paralysis, including that of the quadriceps and sural triceps muscles, whose medullary nucleus may be included in the syndrome. As, in such a situation, the causes of defective vascularisation are maximal and the forces of compression created by muscle tonicity, minimal, it seems logical that growth defects should also be the most severe.

It seems very likely that the flaccid character of paralysis helps to aggravate deficient growth. If this was confirmed by a large-scale investigation, it could be explained in the context of the myelomeric levels described above. Flaccid paralysis resulting from a high cord lesion, injures both the neurovegetative centres and the anterior horn cells, and has corresponding repercussions on vascularisation, on the forces of compression exerted by the muscles, and therefore on growth.

At first sight, the complete or incomplete nature of paralytic injury does not influence deficient growth. The term 'incomplete' includes many varied neurological conditions (from minimal remains of sensation to minor motor paralysis where walking is possible) that it seems impossible to define it.

The type of radiotherapy which was formerly used may have been expected to have had a negative effect on spinal growth and perhaps also on that of the lower limbs. In reality, however, the disorders caused by radiotherapy do not seem to have much effect on spinal growth as a whole, because it is localised to one or two vertebral segments. Neither do they affect lower limb growth, as their medullary consequences are probably superimposable on those of the lesional syndrome. 
The present investigation does not solve all the problems raised by the relationship between growth and the nervous system. However the results do not contradict previously formulated hypotheses, and provide evidence in support of the theory that vascular and mechanical disorders are caused by a multifactorial mechanism which might lead to post-paralytic growth defects.

The scope of this type of study should be enlarged and extended in two main directions: in the first place, a larger series of subjects with cord injury must be available than the I 4 we were able to study, but this number can only be exceeded by a co-ordinated study on a national scale. Secondly, in addition to cord injury, it would be desirable to examine the part played by cerebral lesions, which might also be responsible for growth deficiencies.

\section{RÉSUMÉ}

Après un rappel bibliographique des données cliniques et expérimentales concernant les défauts de croissance consécutifs aux atteintes du système nerveux périphérique survenues dans l'enfance, les auteurs proposent une analyse semilongitudinale des valeurs anthropométriques de jeunes paraplégiques par section médullaire.

Ils mettent en évidence un défaut de croissance moyen, de l'ordre de deux écarts-type, qui touche exclusivement le segment inférieur et épargne le segment supérieur, même au décours des paralysies de niveaux myélomériques supérieurs cervical ou dorsal. Les défauts de croissance sont d'autant plus importants, que le niveau myélomérique est bas et la paralysie précoce. Les auteurs proposent une interprêtation de ce fait.

\section{ZUSAMMENFASSUNG}

Die Autoren rufen zuerst in gedächtnis die literatur über die klinischen und experimentellen Angaben betreffenden die Wachstumsfehlen folgenden auf einer des peripherischen Nerveusystems in Kindheit vorfallener Verletzung zurück. Daun auseinandersetzen sie eine halblongitudinale Analyse der anthropometrischen werten von jungen Traumatisch Quergelähmten.

Sie stellen ein durchschnittliches Wachstumfehlen von zwei 'Standart deviation' klar. Dieses befällt nur die untere Gliedmassen und Verschont die obere, selbst werm die Lähmung Hals-oder obere Rückenwirbel trefft. Das Wachstumsfehlen ist um so grösser als der Werletzungsetand ist niedriger und die Paralyse früher. Die Verfasser legen eine Ausdeutung dieser Tat dar.

\section{REFERENCES}

Bara, J. S. (1948). Growth and inequality of leg length in poliomyelitis. New England fournal of Medicine, 238, 737-743.

Blount, W. P. (I956). Inequality in length of the lower extremities. The significance of leg length in PAA. In: Campbell's Operative orthopaedics. 3rd edn. pp. I829. London: Henry Kimpton.

Duval-Beaupere, G. \& Soulignac, G. ( I 975). Premature pubarche and the growth of the trunk in paralysed children. Annals of human biology, 2, I, 69-80.

Fanconi, Perabo, Legrand \& Taillard, (I959). Les inégalités de longueur de membres inférieurs dans les séquelles de PAA Rapport du symposium de l'Association européenne contre la PAA Munich.

FloRenSA, G. (1965). Les inégalités de longueur au cours des séquelles de PAA de l'enfant. Annales médeciné Physique, 8, 3, I-8.

Frost, H. M. (1979). A chondral modeling theory. Calcified Tissue International, 28, I 8 I-200.

Gill, C. G. \& Авотт, L. C. (1942). Practical method of predicting the growth of the femur and tibia in the child. Archives of Surgery, 45, 286-3 5.

GREEN, W. T. (I 949). Discussion after prediction of inequal growth of the lower extremities in anterior poliomyelitis. Fournal of Bone and foint Surgery, 31 A, 484-485. 
Gullickson, G. J., Olson, M. \& Kottke, F. J. (1950). The effect of paralysis of one lower extremity on bone growth. Archives of physical medecin, 31, 392-400.

Herzig, E. \& Root, W. S. (1959). Relation of sympathetic nervous system to blood pressure of bone marrow. American fournal of Physiology, 196, 1053-1056.

Jaeger Denavit, O., Gaussel, J., Bedoiseau, M., Pannier, S., Lacert, Ph. \& Grossiord, A. (1969). Vasomotricité cutanée chez les paraplégiques. Presse Médicale, 77, 35, I 207-I 209.

LeCOEUR, P. (I98I). Personal communication.

MCEIlfResh, E. C. \& Kelly, P. J. (1974). Effect of sympathectomy and sciatic nerve stimulation on bone blood flow. Surg. Forum, 25, 483-485.

Mineiro, J. D. (1965). Coluna vertebral humana, alguno aspectos da sva estrutura et vasculari, Zaçâo. Sociedade Industrial Grafica Lisboa, 277 p.

Person, B. M. (I968). Growth in length of bones in change of oxygen and carbon dioxide tension. Acta Orthopaedica Scandinavica, 177.

RATLIfF, A. H. C. (1959). The short leg in PAA. Fournal of Bone and foint Surgery, 41B, I, 56-69.

RING, P. A. (I957a). Paralytic bone lengthening following poliomyelitis. Lancet, 2, 55 I-553.

RING, P. A. (I957b). Shortening and paralysis in poliomyelitis. Lancet, 2, 980-983.

RING, P. A. (1958). Prognosis of limb inequality following paralytic poliomyelitis. Lancet, 2, I306-1308.

Salaire, M. (1963). Les inégalités de longueur des membres inférieurs dans la poliomyélite. Revue de Chirurgie Orthopédique et réparatrice, 49, 252-26I.

SELYE, H. \& BAJUSK, E. (I958). Effect of denervation on experimental induced changes in the growth of bone and muscle. American fournal of Physiology, 192, 2, 297-300.

Silver, J. R. (1965). Circulatory reflexes in spinal man. Paraplegia, 2, 235-245.

Showing, J. \& Celers, J. ( I 965). Compte rendu hebdomadaire des séances de l'Académie des Sciences. Vol 260, 19, 5104.

Stinchfield, A. J., Reidy, J. A. \& BARR, J. S. (1949). Prediction of uniqual growth : he lower extremities in PAA. Fournal of Bone and foint Surgery, $3 \mathbf{I A}, 478$.

TAIllard, W. (1959). Troubles de la Croissance osseuse dans les séquelles de PAA. Médecine et Hygiène, 422, 93-94.

Trott, A. W., Nesline, M. D. \& Green, W. T. (I958). The chronology of circulatory changes in poliomyelitis. Fournal of Bone and foint Surgery, 40A, 245-255.

TrotT, A. W. (I968). Peripheral circulatory changes in patients with poliomyelitis. Clinical Orthopaedica and Related Research, 61, 2 13-222.

Troupp, H. (196I). Nervous and vascular influence on longitudinal growth of bone: an experimental study on rabbits. Acta Orthopaedica Scandinavica, I I, 7-22.

Trueta, J. (1958). Vascularisation et Ostéogénèse. Revue de Chirurgie Orthopédique et réparatrice, 44, I, 3-23.

Trueta, J. \& Armato, J. P. (I960). The vascular contribution to osteogenesis. Study by injection method. Fournal of Bone and foint Surgery, 42B, 97-I09.

Trueta, J. \& ARmato, J. P. (I960). The vascular contribution to osteogenesis. Study with the electron microscop. Fournal of Bone and foint Surgery, 42B, 367-376.

Trueta, J. \& ARmato, J. P. (I960). The vascular contribution to osteogenesis. Changes in growth cartilage cause by experimental induced ischemia. Fournal of Bone and foint Surgery, 42B, 571-587.

Trueta, J. \& ARmato, J. P. (I96I). The vascular contribution to osteogenesis. The effect of pressure up on the epiphysial. Fournal of Bone foint Surgery, 43B, $800-813$

de Valderrama, J. F. \& Trueta, J. (1965). The effect of muscle action in the intra osseos circulation. Fournal of Pathology and Bacteriology, 89, 179-186.

Van der Hoeft, P. S., Kelly, P. J., Janes, J. M., Peterson, L. F. A. (I963). Croissance différentielle d'os homonymes droit et gauche sous l'effet d'une fistule artérioveineuse droite. Etude quantitative à l'aide de Tétracycline. Biological Académy Royal Medicine. Bruxelle VII tome III, 5, 363-373.

Wo, Y. K. \& MiLtNeR, L. J. (1937). A procedure for stimulation of longitudinal growth of bone. Fournal of Bone and foint Surgery, 19, 909-921. 